\title{
研究課題別事後評価結果
}

1. 研究課題名

環境影響と効用の比較評価に基づいた化学物質の管理原則

2. 研究代表者名及び主たる研究参加者名（研究機関名・職名は研究参加期間終了時点）

研究代表者 中西 準子 横浜国立大学環境科学研究センター 教授

主たる研究参加者 益永 茂樹 横浜国立大学環境科学研究センター 教授

田中嘉成横浜国立大学環境科学研究センター 客員助教授

岡 敏弘福井県立大学経済学部 教授

3. 研究内容及び成果

巌佐 庸

九州大学理学部 教授

化学物質の利用による環境リスクとベネフィットの両者を考慮して、化学物質の管理原則を導き出すための

基礎となる科学的なフレームワ一クを提出することが本研究プロジェクトの目的である。そのために、リスク 評価手法の開発と事例研究を通じて、各種解析手法を開発することを目標とした。以下、内容及び成果を大き く3つに分けてその概要を分説する。

(1) リスク評価手法開発

リスク評価については、異種のリスク評価が可能な共通尺度として、人間の健康リスク評価のために損失余 命 (LLE) を、生態リスク評価のために種の絶滅確率を提案し、その手法開発と応用を研究目標とした。

人間の健康リスクについては、横浜国立大学環境科学研究センターにおいて研究代表者を中心に研究が推進 された。研究の成果として、損失余命 (LLE) という尺度を用いて異種のリスクについての評価法を開発し提 案した。ここで、異種とは発ガンリスクとその他の病気に関するリスク、さらには通常死亡率の上昇を確認で きないような軽微な影響のリスクなどを指す。

今後の課題としては、軽微な影響（損失余命が1年以内など）の評価には、かなり鈍感な尺度であることも 明らかとなつた。今後、生活の質 (QOL : Quality of Life) を基にしたQALYや英国や米国で使われているリス ク削減のための支払い意思額（WTP：Willingness to Pay）などについての展開が必要である。

生態リスク評価についての研究は、九州大学理学部を主体に研究が進められた。種の絶滅確率を尺度とする ことを目標にして研究が進められた。絶滅確率については、絶滅危惧種については1/Tを、安定な生物集団に 対してはlogT、または丁を採用することが提案された。

生態リスクについては、種間相互作用を考慮したCASMモデルを琵琶湖、諏訪湖へ適用し、化学物質規制へ の利用を提案した。また、食物連鎖を通じた上位栄養段階にある生物へのリスク評価モデルも構築し、それを 用いてリスク評価を行なった。

リスク・ベネフィィット解析に゚いては、環境対策等の削減費用とそれに伴うコストを比較して、B/R比 $=$ ベネ フィットリリスクの大小で、その政策の効率を評価し、効率のよい政策を選択するという化学物質管理原則を提 案した。

本研究は、環境中での化学物質の影響を真摰に調べるという点では基礎研究であるが、一方では実践的、政 策的な科学的側面を有していると言える。このため、研究グループは、工学者、理学者、経済学者で構成され

た。 (2) 事例研究

横浜国立大学環境科学研究センターにおいて、下記のような事例研究が行なわれた。その中で、具体的な解 析手法を開発し、提案している。

1) ダイオキシン類の解析

最も広範囲に事例研究が行なわれたのは、ダイオキシン（多塩素化ジベンゾダイオキシン/多塩素化ジベ ンゾフラン）についてであった。この研究の特徵は、有害性がないとされているコンジェナーについても 分離定量し、解析に用いたこと、コンジェナー毎の物理化学的な性質の違いを考慮した解析を行ったこと である。

生物圏動態では、プランクトンから魚類までの食物連鎖上での栄養段階との関連、さらには鳥類（カワ ウなど）への蓄積とそのリスク評価などの研究が行われた。また、発生源解析では、東京湾、宍道湖など の底質の分析を通して、主要な発生源として焼却の他に水田除草浏があることを見出した。新しく見出し たこれらの発生源は、ダイオキシンのリスク評価に大きな影響を与える因子となっていることを明らかに した。人の健康リスク評価を行い、胎児に対するリスクも評価した。リスクマネジメントでは、焼却炉の ダイオキシン対策のリスク・ベネフィット解析を行い、施策の妥当性を検討した。

2 ) 自動車排ガス由来のベンゼン

常時モ二タリングの結果をインターネットで広報すると同時に、その結果を用いて全国のベンゼン濃度 を推定し、リスク評価を行った。それをもとにベンゼン削減策のリスク・ベネフィット解析を行った。

3 ) アマゾン流域の水銀污染について、現地調査を基に水銀によるリスクの推定を行った。

4 ) DDTによるセグロカモメ、八イタカに対するリスク評価を行った。生態リスクは、生息地消失換算リスク という尺度で評価した。DDT禁止政策についての、リスク・ベネフィット解析を行った。

5 ）中池見湿地（福井県）開発に伴う絶滅危惧種15種について、期待多様性損失を算出した。これは、個々の 生物リスクではなく、生態系全体のリスクを表現したものである。リスク・ベネフィット解析も行なった。

6 ）愛知万博予定地の開発に伴う絶滅危惧種27種の絶滅リスク増加分を算出した。

7 ）85の安全、環境対策の費用効果分析（リスク・ベネフィット解析）を行った。

8 ） 13の物質（ディーゼル排出物、ベンゼン、ホルムアルデヒド、ラドン、クロロピロフォス、トルエン、キ シレン、ヒ素、クロルデン、DDT、ダイオキシン、カドミウム、水銀）について、LLEを用いて日本人の 
リスクを評価し、比較した。

\section{(3) 発生源解析}

上記の事例研究において、環境情報から発生源を推定する解析手法を開発し、(1)ダイオキシンの発生源、(2) ベンゼンについてのPRTRデータの検証、(3)関東域ダイオキシン排出量推定、(4)工業地帯におけるプロピンの 発生源、のような例について応用した。

4. 事後評価結果

4 - 1. 外部発表（論文、口頭発表等）、特許、研究を通じての新たな知見の取得等の研究成果の状況 本研究は、人間の健康りスク及び生態系のリスク評価について新しい評価手法を開発したもので、その独創

性について大きな貢献が認められる。提案された新しい尺度はリスク評価に新しい局面を拓いたといえる。 また、多くのリスク・ベネフィット評価について事例研究を行なつた。ダイオキシンなどの発生源解析におい ても、大きな成果を得ている。

全体の研究は、研究進捗のためのシステム樹にしたがって、研究代表者の十分な管理の下で進められた。こ

れらの個々の重要なステップにおいて着実な成果を得ている。研究構想を着実に実行した研究と評価できる。 また、共同研究者は分担した役割を十分果たしたものとみなされる。すなわち、研究代表者のリーダシップ 並びに研究チームの協調はきわめて適正であつた。

多くの重要論文を適切に発表している。論文発表件数は、英文114件、和文56件にのぼつた。研究代表者の 主な論文として、Risk-benefit analysis of prohibition of the mercury electrode process in caustic soda production. Environmental Engineering and Policy, 1，3-9 (1998) などがある。この他、ワークショップ の内容が国際的な学術雑誌であるChemosphere特集号に掲載されたことも特筆される。また、学会発表も国 内学会101件、国際学会50件行われた。

ちようど化学物質問題が社会の注目を集めた時期と重なったために、研究成果もその都度広く社会に知られ

ることになり、新聞報道は32件にのぼつた。

$4-2$. 得られた研究成果の科学技術への貢献 研究成果は、リスクを数量的に検討し評価するアプローチが確立されているため、科学的そして行政的にイ ンパクトを与えるものであると評価できる。

特筆すべき点は、本研究の成果であるリスク評価に基づく管理基準の評価は、今後新たに発生する可能性の

ある化学物質のリスク評価と管理基準の制定に重要な役割をはたすことが期待できる点である。

生態系における種多様性へのインパクト評価などは、かなり水準が高いと評価できる。特に、環境ホルモン などによる生物種被害の評価は重要な問題となる。提案されたアプローチは今後重要な役割を果たすものと評 価できる。

ダイオキキシンの発生源解析においては、主要な発生源として焼却のほかに、過去の水田除草剂の影響がある ことを初めて見出した。このことは、ダイオキシンのリスク評価に新しいインパクトを与えたものと評価でき 受賞関係では、研究代表者が平成10年度「環境管理」優秀論文賞ほか 2 件を受賞した。

4 - 3. その他の特記事項

国際ワークショツプを4回実施している。出席者は、行政、産業界などを含めて毎回盛会であつたが、これ

はこの研究のもつ社会的な位置付けを示したものとみなすことができる。

研究代表者は、13年 4 月より、独立法人産業技術総合研究所化学物質リスク管理研究センターのセンター長 に就任した。

戻る 